\title{
Solid Phase Extraction to On-Line Preconcentrate Trace Cadmium Using Chemically Modified Nano-Carbon Black with 3-Mercaptopropyltrimethoxysilane
}

\author{
Caroline D. Zappielo, ${ }^{a}$ Daniel M. Nanicuacua, ${ }^{a}$ Walter N. L. dos Santos, ${ }^{b}$ Daniel L. F. \\ da Silva, ${ }^{b}$ Luiz H. Dall'Antônia, ${ }^{a}$ Fernanda M. de Oliveira, ${ }^{a}$ Débora N. Clausen ${ }^{a}$ and \\ César R. T. Tarley*,a,c
}
${ }^{a}$ Departamento de Química, Universidade Estadual de Londrina, 86051-990 Londrina-PR, Brazil
${ }^{b}$ Departamento de Ciências Exatas e da Terra, Universidade do Estado da Bahia, Campus I, 41195-001 Salvador-BA, Brazil

'Instituto Nacional de Ciência e Tecnologia (INCT) em Bioanalítica, Departamento de Química Analítica, Instituto de Química, Universidade Estadual de Campinas (UNICAMP), 13083-970 Campinas-SP, Brazil

\begin{abstract}
Carbon black (CB) grafted with 3-mercaptopropyltrimethoxysilane (3-MPTMS) was used as solid phase extractor for $\mathrm{Cd}^{2+}$ in a flow injection system coupled to flame atomic absorption spectrometry (FAAS). The influence of $\mathrm{pH}$, buffer concentration, preconcentration flow rate and eluent concentration on preconcentration of $\mathrm{Cd}^{2+}$ were investigated by means of chemometric tools. The characterization of the adsorbent chemically modified was performed by Fourier transform infrared, scanning electron microscopy, energy dispersive X-ray spectroscopy, thermogravimetric analysis, Raman spectroscopy and textural analysis. To perform the on-line preconcentration, $20.0 \mathrm{~mL}$ of a pH $7.0 \mathrm{Cd}^{2+}$ solution at a flow rate of $4.0 \mathrm{~mL} \mathrm{~min}^{-1}$ was loaded through $30.0 \mathrm{mg}$ of modified $\mathrm{CB}$ and then eluted with $1.0 \mathrm{~mol} \mathrm{~L}^{-1} \mathrm{HCl}$ toward the FAAS instrument. The limits of detection and quantification were found to be 0.20 and $0.66 \mu \mathrm{g} \mathrm{L^{-1 }}$, respectively. Addition and recovery tests carried out in real samples (mineral, tap and saline waters, and cigarette sample) and the analysis of certified reference material (TORT-2, lobster hepatopancreas reference) attested the applicability of proposed method.
\end{abstract}

Keywords: nano-carbonaceous material, silanization, $\mathrm{Cd}^{2+}$, atomic absorption spectrometry

\section{Introduction}

Cadmium is a toxic metal found in low concentrations in the three environmental compartments, air, water and soils. However, due to increase of human activity, industrial and agricultural, its level has been increasingly elevated mainly in soil, surface water and plants. ${ }^{1}$ The major sources of cadmium in drinking water are corrosion of galvanized pipes, erosion of natural deposits, discharge from metal refineries, runoff from waste batteries and paints. ${ }^{2}$ Through the food chain, cadmium is transferred from environment into animals and human beings. The maximum levels recognized for potable water by national guidelines is $5.0 \mu \mathrm{g} \mathrm{L}^{-1}$, established by the United States Environmental Protection Agency (US EPA) ${ }^{3}$ and Brazilian

*e-mail: ctarleyquim@yahoo.com.br
Health Surveillance Agency (ANVISA). ${ }^{4}$ Some people who drinks water containing cadmium above the maximum contaminant level for many years could experience kidney damage. ${ }^{5}$ Tobacco is also an important source of cadmium uptake by humans because tobacco leaves accumulates high levels of cadmium. ${ }^{6}$

The determination of cadmium ions has been usually carried out through spectroanalytical techniques such as flame atomic absorption spectrometry (FAAS), ${ }^{1,7}$ graphite furnace atomic absorption spectrometry (GF AAS $)^{8,9}$ and inductively coupled plasma optical emission spectrometry (ICP OES). ${ }^{10-12}$ The interest in FAAS comes from their high selectivity and low cost. However, due to the high limit of detection (LOD) of this technique, conventional separation enrichment procedures, mainly the solid phase extraction (SPE) ones, have been frequently used to overcome interferences from matrix elements and 
to improve the limits of detection. ${ }^{13,14}$ In particular, the adsorbent preconcentration flow injection systems have been seen as a very useful tool because of the simplicity, high preconcentration factors, easy regeneration of the solid phase, low consumption of sample and reagents and high sample throughput. ${ }^{15}$ Although SPE associated with flow injection systems has been very well recognized as an efficient analytical tool for improving the detectability of spectroanalytical techniques, its success depends on selective and adsorptive performance of adsorbent.

The carbonaceous nanomaterials, such as carbon nanotubes (CNTs), ${ }^{7,16-18}$ fullerene, ${ }^{19}$ activated carbons $\mathbf{s}^{1,12,20}$ and graphene, ${ }^{21}$ show interesting properties as adsorbent for metal ions due to its structure, mechanical (high resistance) and chemical properties and large surface area. In spite of these properties, the search for alternative and low cost nano-carbonaceous material with similar properties has been increasingly investigated. Carbon black (CB) has emerged as an alternative nanomaterial although very little research has been focused on metal ion preconcentration for the development of highly sensitive analytical methods. This material has been widely consumed in automotive-related rubber product applications due to its reinforcing action ${ }^{22}$ and also used as a versatile material as a catalys $\mathrm{t}^{23}$ and conductive material. ${ }^{24}$ The particle size of $\mathrm{CB}$ is partially in the nanometer range with average values between 20 and $300 \mathrm{~nm}$ according to different production process. This is similar to the diameter of the fullerene and the thickness of carbon nanotube and graphene. ${ }^{25} \mathrm{CB}$ is composed of 90-99\% elemental carbon, with oxygen and hydrogen as the other major constituents, which can be distributed in the carbonaceous matrix in various organic functional groups such as hydroxyl $(-\mathrm{OH})$, carbonyl $(\mathrm{C}=\mathrm{O})$ and carboxyl $(\mathrm{COOH})$. In addition to these elements, $\mathrm{CB}$ may contain small amounts of nitrogen and sulfur, depending upon the nature of hydrocarbons used in the manufacture. ${ }^{22,26}$ This nanomaterial can be obtained from the partial combustion or thermal decomposition of hydrocarbons. The primary particles of $\mathrm{CB}$ exhibits a spherical shape and it presents a strong tendency to agglomerate, because of strong Van der Waals forces among the surface of the CB nanoparticles, affecting their dispersion in polar medium. ${ }^{25}$ Altering the surface chemistry of CB is sometimes necessary to solve this drawback and also to improve the dispersability, chemical stability as well and the performance to adsorb metals ions. ${ }^{26}$ The modification with oxidizing agent provides higher dispersion stability in aqueous medium due to increase of hydrophilic functional groups located at the edges of carbon layer plane such as hydroxyl, carbonyl and carboxyl, which are responsible for surface reactivity of $\mathrm{CB} .{ }^{27-29}$ Silanization is another very popular method to improve dispersion. Some studies have reported the use of organosilane grafted carbon nanotubes showing satisfactory sorption capacity for chromium, arsenium and selenium ${ }^{30}$ and lead, ${ }^{31,32}$ but currently studies regarding development of CB modified with organosilanes as adsorbent for metal ions have not been found in the literature.

In this direction, this paper reports the modification of CB with 3-mercaptopropyltrimethoxysilane (3-MPTMS) aiming at the development of a preconcentration flow injection system for $\mathrm{Cd}^{2+}$ determination in water samples, cigarette and biological sample by FAAS. 3-MPTMS has been chosen due to the thiol group ( $\mathrm{SH}$ ) on its structure, which confers to the molecule, according to Pearson theory, properties of soft base capable to strongly interact with $\mathrm{Cd}^{2+}$ cation. ${ }^{33}$ Taking into account that application of modified CB in the field of separation science is in its infancy and the absence of similar reports in the literature, the present study provides new insight into application of alternative nano-carbonaceous adsorbents on the preconcentration studies aiming at metal ions determination at low levels.

\section{Experimental}

\section{Apparatus}

The absorption measurements were carried out using a flame atomic absorption spectrophotometer (Shimadzu ${ }^{\circledR}$ AA-7000, Kyoto, Japan) equipped with a hollow cathode lamp for cadmium. The hollow cathode lamp was operated at $8 \mathrm{~mA}$ and a wavelength of $228.8 \mathrm{~nm}$. The flame used was comprised of air-acetylene with a flow of $2.0 \mathrm{~L} \mathrm{~min}^{-1}$. For the propulsion of the solutions a peristaltic pump (Ismatec ${ }^{\circledR}$ IPC-08, Glattzbrugg, Switzerland) and Tygon ${ }^{\circledR}$ tubing were used and an injector was used for steps of preconcentration and elution. $\mathrm{pH}$ measurements were performed using a pH meter (Metrohm ${ }^{\circledR} 827$ pH lab, Herisau, Switzerland). Infrared spectra were recorded in a Shimadzu ${ }^{\circledR}$ Fourier transform infrared (FTIR) spectrophotometer FTIR-8300 (Tokyo, Japan) in the transmission range of $400-4000 \mathrm{~cm}^{-1}$. The morphology of the materials was evaluated using a FEI Quanta 200 scanning electron microscope (SEM; Philips ${ }^{\circledR}$, Amsterdam, Netherlands). Micrographs were obtained by applying an electron acceleration voltage of $20 \mathrm{kV}$ after the materials were covered with a thin layer of gold. Average pore sizes and volumes of materials were estimated by Barrett-Joyner-Halenda (BJH) method based on nitrogen sorption experiments, whereas the specific surface areas were determined from sorption isotherms according to Brunauer-Emmett-Teller (BET) method and before analysis the samples were previously dried at $130^{\circ} \mathrm{C}$ for $4 \mathrm{~h}$ in vacuo. 
Raman spectra were recorded using a DeltaNu Advantage laser Raman spectroscopy system (Laramie, WY, USA) at an excitation beam of $532 \mathrm{~nm}$ exposed during $15 \mathrm{~s}$ to prevent damage caused by laser irradiation. The spectra were measured in the range $200-3400 \mathrm{~cm}^{-1}$ to evaluate the first-order Raman spectra. Thermal analysis was performed on a TGA 4000 thermogravimetric analyzer (PerkinElmer ${ }^{\circledR}$, Waltham, MA, USA). About $15 \mathrm{mg}$ of materials were heated from 30 to $900^{\circ} \mathrm{C}$ at a scan rate of $10^{\circ} \mathrm{C} \mathrm{min}{ }^{-1}$ under nitrogen atmosphere $\left(20 \mathrm{~mL} \mathrm{~min}^{-1}\right)$. Sample decomposition of certified reference material was performed in a microwave oven model Ethos One (Milestone ${ }^{\circledR}$ microwave laboratory system, Italy). Statistica ${ }^{\circledR}$ software package was used to process the factorial experimental data (Statsoft, Tulsa, OK, USA).

\section{Reagents}

The reagents and solvents used in the preparation of modified CB were: nitric acid (70\% purity), hydrochloric acid (37\% purity), 3-mercaptopropyltrimethoxysilane ( $95 \%$ purity) as a modifying agent and ethanol as solvent, all acquired from Sigma-Aldrich ${ }^{\circledR}$ (St. Louis, MO, USA). Commercial Vulcan XC-72R carbon black was kindly supplied by Cabot Corporation ${ }^{\circledR}$ (São Paulo, SP, Brazil). Tris(hydroxymethyl)aminomethane hydrochloride (Tris-HCl) was obtained from Sigma-Aldrich ${ }^{\circledast}$ (St. Louis, MO, USA) and sodium acetate and ammonia were prepared from their respective salts (Merck ${ }^{\circledR}$, Darmstadt, Germany) without further purification. $\mathrm{H}_{2} \mathrm{O}_{2}$ (Sigma-Aldrich ${ }^{\circledR}$, St. Louis, MO, USA) was used for sample decomposition procedures. Humic acid powder was acquired from SigmaAldrich $^{\circledast}$ (St. Louis, MO, USA) and it was dissolved in a $1.0 \mathrm{~mol} \mathrm{~L}^{-1} \mathrm{KOH}$ solution.

All aqueous solutions were prepared using ultrapure water from a Milli- $\mathrm{Q}^{\circledR}$ System (Millipore ${ }^{\circledR}$, Billerica, MA, USA). A $1000 \mathrm{mg} \mathrm{L}^{-1} \mathrm{Cd}^{2+}$ stock solution was purchased from Merck ${ }^{\circledR}$ (Darmstadt, Germany) and working solutions were made by stepwise diluting the stock solution with ultrapure water. Solutions of $\mathrm{Co}^{2+}, \mathrm{Zn}^{2+}$, $\mathrm{Ni}^{2+}, \mathrm{Cu}^{2+}, \mathrm{Sb}^{2+}, \mathrm{Pb}^{2+}, \mathrm{Fe}^{3+}, \mathrm{As}^{3+}, \mathrm{Ca}^{2+}, \mathrm{Ba}^{2+}$ and $\mathrm{Mg}^{2+}$ used in the interference studies were prepared from their stock solutions (1000 $\left.\mathrm{mg} \mathrm{L}^{-1}\right)$ or from their salts. $\mathrm{pH}$ values of solutions were adjusted with $\mathrm{NaOH}$ and/or $\mathrm{HNO}_{3}$.

\section{Synthesis of the modified carbon black (3-MPTMS-grafted} $\mathrm{CB})$

Carbon black $(2.0 \mathrm{~g})$ was oxidized in refluxing with $50 \mathrm{~mL}$ of a $\mathrm{HNO}_{3}: \mathrm{H}_{2} \mathrm{SO}_{4}(3: 1, \mathrm{v} / \mathrm{v})$ mixture at $65{ }^{\circ} \mathrm{C}$ for $2 \mathrm{~h}$. ${ }^{7,34}$ This procedure was required to create more binding sites onto CB surface, mainly hydroxyl groups capable to react with 3-MPTMS. Then, the oxidized CB was washed with ultrapure water until the $\mathrm{pH}$ of the filtrate became stable (pH ca. 7.0) and finally dried at $100{ }^{\circ} \mathrm{C}$. Afterwards, $1.65 \mathrm{~g}$ of the oxidized CB were dispersed in $100 \mathrm{~mL}$ of ethanol and kept in an ultrasonic bath for $30 \mathrm{~min}$. To grafting process, according to references ${ }^{35,36}$ with minor modifications, $300 \mu \mathrm{L}$ of the modifier agent 3-MPTMS were added and kept under reflux at $65{ }^{\circ} \mathrm{C}$ for $3 \mathrm{~h}$. After that, 3-MPTMS-grafted CB (synthetized material) was dried at $50^{\circ} \mathrm{C}$ for $12 \mathrm{~h}$.

\section{Preconcentration procedure using flow injection system coupled to FAAS}

The preconcentration system was operated in a timebased mode according to our previous publication. ${ }^{17}$ Twenty milliliter solutions containing $\mathrm{Cd}^{2+}$ (sample or standard solution) buffered with $0.1 \mathrm{~mol} \mathrm{~L}^{-1}$ Tris- $\mathrm{HCl}(\mathrm{pH} 7.0)$ were percolated at a flow rate of $4.0 \mathrm{~mL} \mathrm{~min}^{-1}$ through a home-made cylindrical polyethylene mini-column packed with $30.0 \mathrm{mg}$ of the 3-MPTMS-grafted CB. After preconcentration, the metal ion was eluted from the column with $1.0 \mathrm{~mol} \mathrm{~L}^{-1} \mathrm{HCl}$. Finally, the metal concentration in the solution was determined by FAAS. For the water samples (mineral, tap, saline and lake), $95.0 \mathrm{~mL}$ of samples were employed and the volume was made up to $100.0 \mathrm{~mL}$ in volumetric flasks with $5.0 \mathrm{~mL}$ of $2.0 \mathrm{~mol} \mathrm{~L}^{-1}$ Tris- $\mathrm{HCl}$ solution ( $\mathrm{pH}$ 7.0).

\section{Breakthrough curve}

The breakthrough curve was constructed to determine the breakthrough volume and the maximum sorption capacity (MSC) of 3-MPTMS-grafted CB towards $\mathrm{Cd}^{2+}$ under dynamic condition. The assays were performed by percolating aliquots of $4.0,8.0$ and $10.0 \mathrm{~mL}$ of $0.3 \mathrm{mg} \mathrm{L}^{-1} \mathrm{Cd}^{2+}$ dissolved in $0.1 \mathrm{~mol} \mathrm{~L}^{-1}$ Tris- $\mathrm{HCl}$ $(\mathrm{pH}=7.0)$ through a mini-column packed with $30 \mathrm{mg}$ of 3-MPTMS-grafted CB at a flow rate of $4.0 \mathrm{~mL} \mathrm{~min}^{-1}$, until saturation was reached. Each aliquot was collected and analyzed by FAAS and the amount of cadmium adsorbed on silanized material $\left(\mathrm{Q}, \mathrm{mg} \mathrm{g}^{-1}\right)$ for each aliquot was determined according to equation 1 :

$\mathrm{Q}=\frac{\left(\mathrm{C}_{0}-\mathrm{C}_{\mathrm{f}}\right) \mathrm{V}}{\mathrm{m}}$

where $\mathrm{C}_{0}$ is the initial cadmium concentration $\left(\mathrm{mg} \mathrm{L}^{-1}\right)$, $\mathrm{C}_{\mathrm{f}}$ is the concentration of cadmium in the column effluent ( $\mathrm{m} \mathrm{L} \mathrm{L}^{-1}$ ), $\mathrm{V}$ is the solution volume (in $\mathrm{L}$ ) and $\mathrm{m}$ is the material mass $(\mathrm{g})$. 


\section{Effect of interfering ions}

In order to verify the influence of possible interfering ions on the $\mathrm{Cd}^{2+}$ preconcentration by 3-MPTMS-grafted CB, binary solution of $\mathrm{Co}^{2+}, \mathrm{Zn}^{2+}, \mathrm{Ni}^{2+}, \mathrm{Cu}^{2+}, \mathrm{Sb}^{2+}, \mathrm{Pb}^{2+}, \mathrm{Fe}^{3+}$, $\mathrm{As}^{3+}, \mathrm{Ca}^{2+}, \mathrm{Ba}^{2+}$ or $\mathrm{Mg}^{2+}$ in the presence of $\mathrm{Cd}^{2+}$ were subjected to preconcentration system, under optimized conditions. The studied proportions $(\mathrm{m} / \mathrm{m})$ of $\mathrm{Cd}^{2+}$ and the possible interfering ions were 1:1, 1:5, 1:10, 1:50 and 1:200, and they were compared to the analytical signal obtained to a single solution containing $30.0 \mu \mathrm{g} \mathrm{L}^{-1} \mathrm{Cd}^{2+}$. The influence of organic mater as humic acid was also investigated.

\section{Sample preparation}

The proposed method applicability was verified by analysis of cigarette and saline water samples and three different types of water, i.e., tap, mineral and lake. Tap water was collected at the Londrina State University and lake water came from Lake Igapó III, both located in Londrina, Paraná, Brazil. Lake water has been thoroughly filtered up until be clear. Mineral water and the cigarette samples were obtained from local supermarkets. The saline sample $(0.9 \% \mathrm{NaCl}, \mathrm{m} / \mathrm{v})$ was purchased at a pharmacy in the city of Londrina (PR, Brazil). Aliquots of $95.0 \mathrm{~mL}$ of water samples were taken and the volume was made up to $100.0 \mathrm{~mL}$ in volumetric flasks with $5.0 \mathrm{~mL}$ of $2.0 \mathrm{~mol} \mathrm{~L}^{-1}$ Tris- $\mathrm{HCl}$ solution ( $\mathrm{pH} 7.0$ ). The accuracy was checked by analysis of Lobster Hepatopancreas reference material for trace metals (TORT-2). $500.0 \mathrm{mg}$ of cigarette and $113.0 \mathrm{mg}$ of the TORT- 2 were digested with $10.0 \mathrm{~mL}$ of concentrated nitric acid $\left(\mathrm{HNO}_{3}\right)$ and $4.0 \mathrm{~mL}$ of $30 \%$ hydrogen peroxide $\left(\mathrm{H}_{2} \mathrm{O}_{2}\right)$. Analyses were carried out in triplicate, kept overnight and then digested using microwave oven. ${ }^{37}$ After this step, the samples were heated on a hot plate to near dryness and then cooled down to room temperature. Afterward, the residue was dissolved in $80.0 \mathrm{~mL}$ of ultrapure water with further addition of $5.0 \mathrm{~mL}$ of $2.0 \mathrm{~mol} \mathrm{~L}^{-1}$ Tris- $\mathrm{HCl}$ solution $(\mathrm{pH} 7.0)$ and the volume was made up to $100.0 \mathrm{~mL}$ in volumetric flask. For each sample, blank solutions were prepared.

\section{Results and Discussion}

\section{Characterization of materials}

In order to evaluate the surface morphologies of the materials, SEM images of CB (in natura), oxidized CB and 3-MPTMS-grafted CB were recorded (Figure 1).

As can be observed in Figure 1a, CB presents typical assembled spherical particles with size lower than $500 \mathrm{~nm}$. The effect of oxidation can be evaluated in Figure 1b, which shows clearly aggregation of particles most likely due to intramolecular forces as hydrogen bond ascribed to the functional groups hydroxyl, carbonyl and carboxyl on the surface. ${ }^{38}$ On the other hand, the modification with 3-MPTMS of oxidized CB promoted a new disaggregation of particles although lower than $\mathrm{CB}$, indicating the grafting of 3-MPTMS on the surface owing to the hydrophobic feature of silane agent.

The surface morphology of materials can be related to the textural characteristics as shown in Table 1.

Table 1. Textural properties of the carbon black (CB), oxidized CB and 3-mercaptopropyltrimethoxysilane (3-MPTMS)-grafted CB

\begin{tabular}{lccc}
\hline Material & $\begin{array}{c}\text { Surface area / } \\
\left(\mathrm{m}^{2} \mathrm{~g}^{-1}\right)\end{array}$ & $\begin{array}{c}\text { Pore volume / } \\
\left(\mathrm{cm}^{3} \mathrm{~g}^{-1}\right)\end{array}$ & $\begin{array}{c}\text { Pore diameter } \\
/ \mathrm{nm}\end{array}$ \\
\hline $\begin{array}{l}\text { 3-MPTMS- } \\
\text { grafted CB }\end{array}$ & 455.9 & 1.02 & 10.28 \\
Oxidized CB & 1010.0 & 1.09 & 5.99 \\
$\mathrm{CB}$ & 1573.0 & 2.08 & 6.99 \\
\hline
\end{tabular}

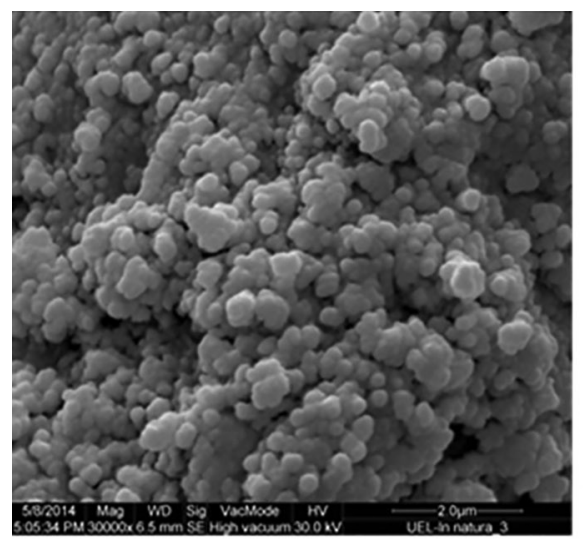

(a)

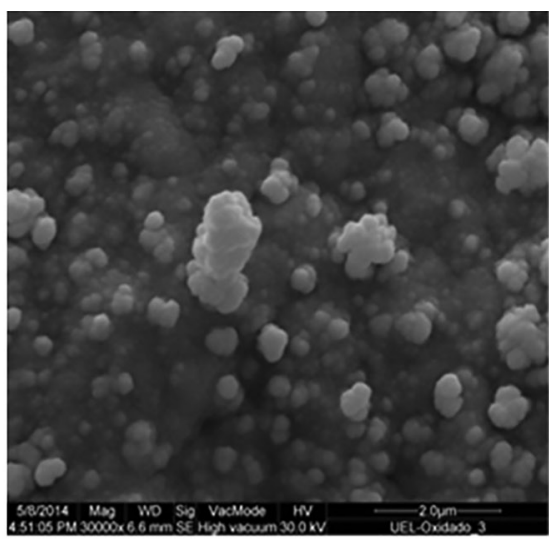

(b)

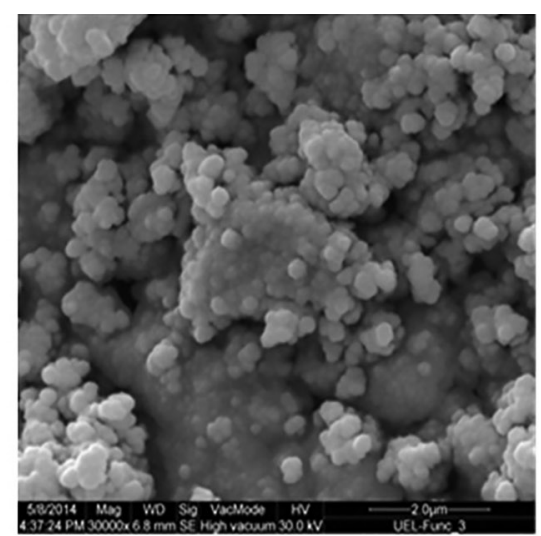

(c)

Figure 1. Scanning electron microscope (SEM) images of (a) carbon black (CB); (b) oxidized CB; and (c) 3-mercaptopropyltrimethoxysilane (3-MPTMS)grafted CB with magnification of 30.000 times. 
The CB shows, as expected, the highest surface area and pore volume. After oxidation process, the surface area significantly decreased and pore volume was reduced in 2 -fold regarding CB. Such result can be rationalized bearing in mind the very high aggregation degree of particles due to presence of hydrophilic functional groups located at the edges of carbon layer plane, thus making the carbon layer nearest each other and, as consequence, decreasing the pore volume and surface area. In regard to CB functionalized with 3-MPTMS, it was found higher pore diameter and the lowest surface area, which can be explained due to insertion of 3-MPTMS agent inside the pores of material. One should note that even though functionalization of CB decrease the surface of material, its surface area is still considered high being suitable to allow the use of these materials for preconcentration. As a brief comparison, the proposed CB functionalized with 3-MPTMS presents higher surface than organosilane-modified multi-walled carbon nanotubes (MWCNT). ${ }^{39,40}$

To investigate the amount of $\mathrm{Si}$ and $\mathrm{S}$ as well as the homogeneous distribution of these elements on the functionalized $\mathrm{CB}$, energy dispersive spectroscopy (EDS) spectrum (data not shown) and elemental mapping were recorded. The EDS images, depicted in Figures $2 b$ and 2c, show absence of detectable phase segregation and element islands, thus showing a good homogeneous dispersion of $\mathrm{Si}$ and $\mathrm{S}$. From the EDS spectra (data not shown) of 3-MPTMS-grafted CB, it was found percentages of C (77.00 wt.\%), O (22.00 wt.\%), Si (0.32 wt.\%), $\mathrm{S}(0.31 \mathrm{wt} . \%)$ and $\mathrm{K}(0.11 \mathrm{wt} . \%)$. The low content of Si and $\mathrm{S}$ is expected owing to the low amount of 3-MPTMS used in the functionalization. In spite of this finding, the silanization reaction is considered successful according to literature data and bearing in mind the $\mathrm{CB} / 3$-MPTMS ratio used. ${ }^{26}$ Furthermore, the low content of S-H group in the material has been enough for improving the detectability of preconcentration method as will be further demonstrated in the figures of merit.

The FTIR spectra of $\mathrm{CB}$, oxidized $\mathrm{CB}$ and 3-MPTMS-grafted CB are depicted in Figure 3. The band around $3440 \mathrm{~cm}^{-1}$ corresponds to $\mathrm{OH}$ stretching vibration from water absorption or hydroxyl groups present in the materials. It is evident that there are many more hydroxyl groups connect to $\mathrm{CB}$ after oxidation process than on pristine $\mathrm{CB}$. The peak at $1630 \mathrm{~cm}^{-1}$ was only observed for pristine $\mathrm{CB}$, which is ascribed to the $\mathrm{C}=\mathrm{C}$ stretching vibration present in the material. ${ }^{41}$ After oxidation process, the spectrum for oxidized CB exhibited a new band at $1585 \mathrm{~cm}^{-1}$, which is attributed to hydroxyl groups or carbonyl groups. ${ }^{42}$ In 3-MPTMS-grafted CB (Figure 3c) this signal is reduced, most likely due to insertion of 3-MPTMS agent inside the pores of material which may have caused the reduction in surface area and pore volume of this CB, as described in its textural properties. The evidence of the silanization comes from the weak signals at 769 and $673 \mathrm{~cm}^{-1}$ due to $\mathrm{Si}-\mathrm{O}$ stretching vibrations. ${ }^{7}$ It must be emphasize that the bands at 1114 and $1118 \mathrm{~cm}^{-1}$ observed, respectively, for $\mathrm{CB}$ and oxidized $\mathrm{CB}$ can be attributed to $\mathrm{C}-\mathrm{O}$ stretching, while the one observed at $1103 \mathrm{~cm}^{-1}$ for 3-MPTMS-grafted CB is attributed to $\mathrm{Si}-\mathrm{O}-\mathrm{Si}$ stretching, which in turn can be overlapped with $\mathrm{C}-\mathrm{O}$ stretching.

The samples were also analyzed by Raman spectroscopy. Results are plotted in Figure 4.

Raman spectra of the materials are characterized mainly by two strong bands: the $\mathrm{G}$ (graphite) band around $1600 \mathrm{~cm}^{-1}$, which indicates the presence of $\mathrm{sp}^{2}$ hybridized

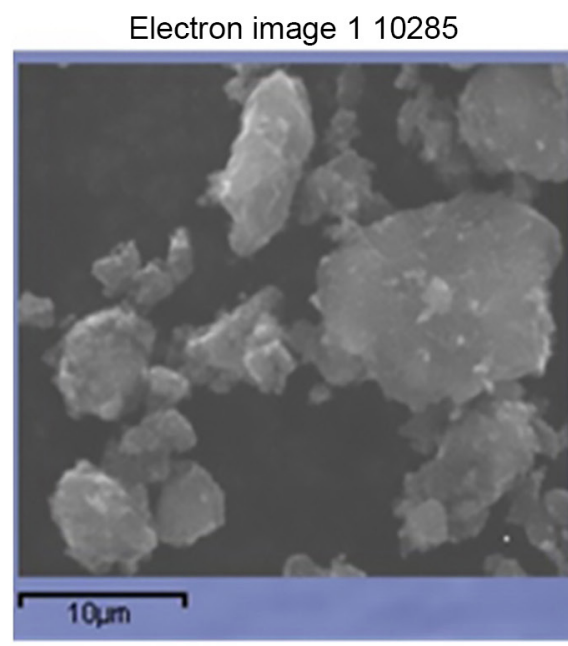

(a)

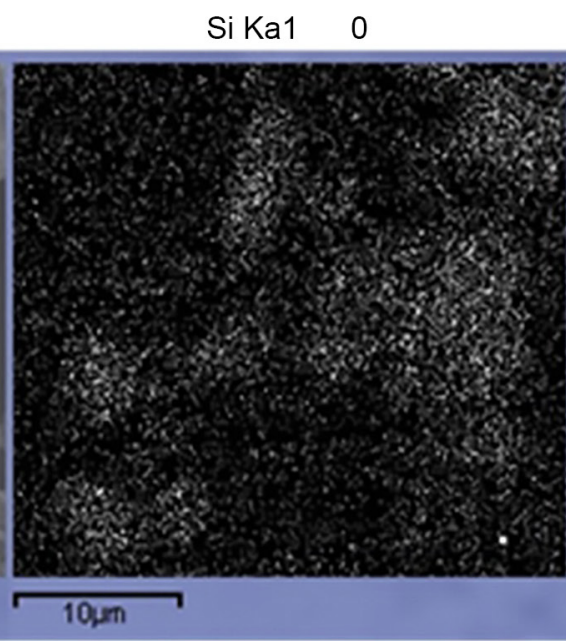

(b)
S Ka1 0

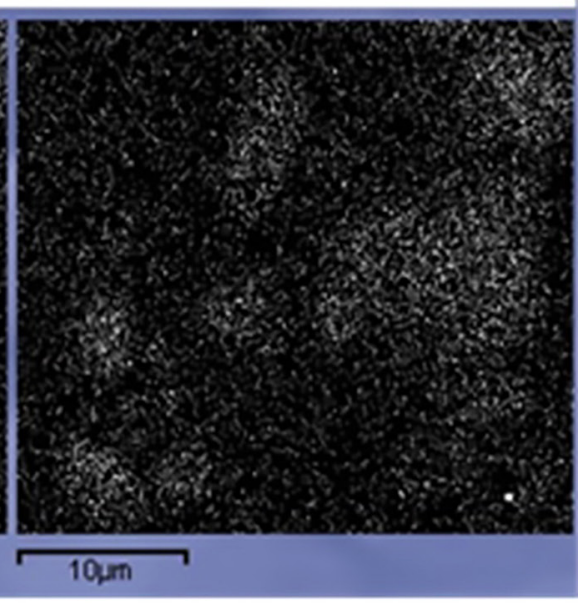

(c)

Figure 2. Scanning electron microscope (SEM) image for (a) 3-mercaptopropyltrimethoxysilane (3-MPTMS)-grafted carbon black (CB); and respective elemental mapping for (b) Si and (c) S. 


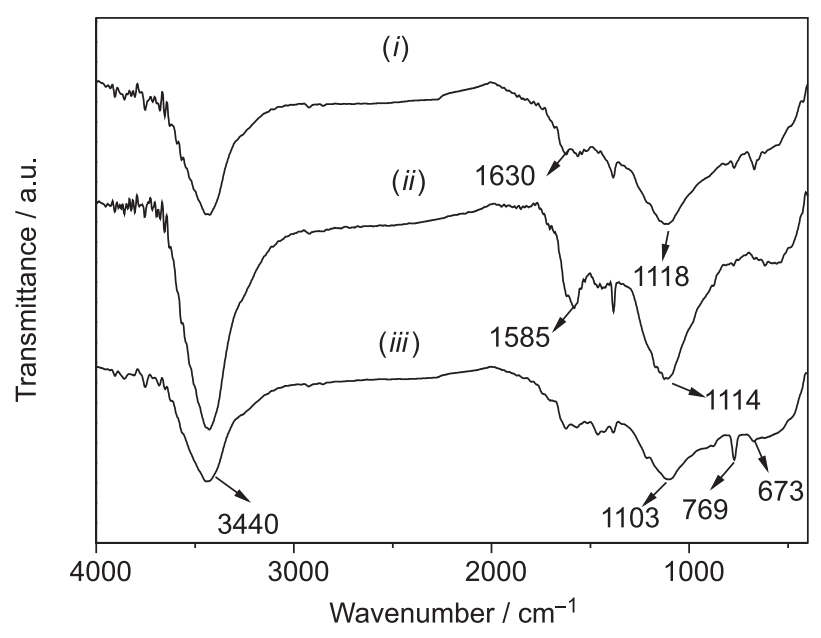

Figure 3. Fourier transform infrared (FTIR) spectrum of ( $i$ ) carbon black (CB); (ii) oxidized CB; and (iii) 3-mercaptopropyltrimethoxysilane (3-MPTMS)-grafted CB.

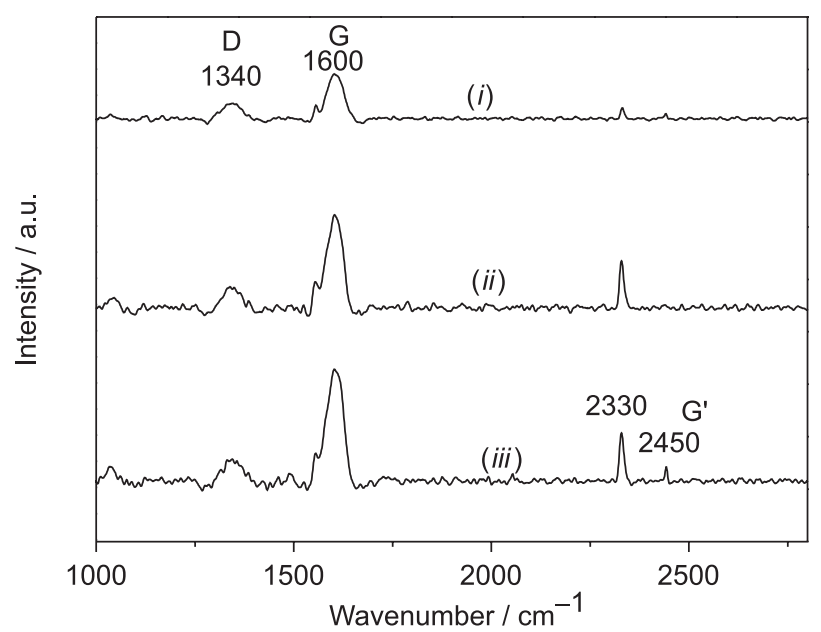

Figure 4. Raman spectra of (i) carbon black (CB); (ii) oxidized CB; and (iii) 3-mercaptopropyltrimethoxysilane (3-MPTMS)-grafted CB. D, G and $\mathrm{G}^{\prime}$ is defect or disorder and graphite bands, respectively.

carbons, and the $\mathrm{D}$ (defect or disorder) band around $1340 \mathrm{~cm}^{-1}$ ascribed to $\mathrm{sp}^{3}$ hybridized carbons. The relative intensity of the bands $D$ and $G\left(\mathrm{I}_{\mathrm{D}} / \mathrm{I}_{\mathrm{G}}\right)$ can be used to evaluate the microstructure of the carbonaceous materials. ${ }^{43}$ From Figure 4 , the $\left(\mathrm{I}_{\mathrm{D}} / \mathrm{I}_{\mathrm{G}}\right)$ ratio were found to be 0.37 for $\mathrm{CB}$, 0.25 for oxidized CB and 0.23 for 3-MPTMS-grafted CB, thus indicating an increase in the order of the graphitic structure of $\mathrm{CB}$ after oxidation and grafting process. ${ }^{36}$ The broad G' peak (around $2450 \mathrm{~cm}^{-1}$ ) presents in the 3-MPTMS-grafted CB can be assigned to an overtone and is due to $\mathrm{D}+\mathrm{G}$ phonons contribution and this band shows evidence of the set 3-MPTMS, suggesting that treatment led to higher order. ${ }^{26}$ The band around $2330 \mathrm{~cm}^{-1}$ presented in all materials comes from the Raman mode of $\mathrm{N}_{2}$ gas present in the air surrounding the sample. ${ }^{44}$

Thermogravimetric curve (TG) and derivative thermogravimetric curve (DTG) for the CB, oxidized CB and 3-MPTMS-grafted CB are depicted in Figures 5a, $5 b$ and 5c, respectively. In Figure 5a, it can be seen that CB presented the highest thermal stability (12\% weight loss) and in the temperature around $44{ }^{\circ} \mathrm{C}$ corresponds to the volatilization of water molecules adsorbed on the material surface. However, the TG of oxidized CB (Figure 5b) showed a large weight loss (45\%), which clearly demonstrates the decrease of thermal stability after oxidation process. The event around $82^{\circ} \mathrm{C}$ can be attributed to losses of residual water adsorbed on the material surface since the oxidation only increases the amount of functional groups already containing oxygen atoms therein in nature. After functionalization with 3-MPTMS, the weight mass was found to be $35 \%$ and the material showed three thermal decomposition events (Figure 5c). The first event took place in the temperature around $65{ }^{\circ} \mathrm{C}$ and it is ascribes to the removal of physically adsorbed water. The second event occurred in the temperature at $348{ }^{\circ} \mathrm{C}$ could be attributed to the decomposition of hydrophilic side groups still present in the material, and the third one observed at $497{ }^{\circ} \mathrm{C}$ is ascribed to thermal decomposition of 3-MPTMS bonded to carbon sheets, as has been reported in literature for carbon sulfur compounds. ${ }^{26,42}$

The lower weight loss of the 3-MPTMS-grafted CB compared to oxidized $\mathrm{CB}$ and, as consequence, a higher ceramic yield is most likely due to the formation of $\mathrm{SiO}_{2}$ during heating, which also confirms the functionalization process. ${ }^{26,27}$

\section{Optimization of the method for cadmium analysis}

After characterization of materials, the on-line preconcentration method for $\mathrm{Cd}^{2+}$ determination by FAAS was optimized using 3-MPTMS-grafted CB as adsorbent by means of a $2^{4}$ full factorial design whose factors $\mathrm{pH}$, buffer concentration $(\mathrm{BC})$, preconcentration flow rate (PFR) and eluent concentration (EC, $\mathrm{HCl}$ ), their levels and obtained results are presented in Table 2 . The experimental design was carried by loading $20.0 \mathrm{~mL}$ of $30.0 \mu \mathrm{g} \mathrm{L}^{-1} \mathrm{Cd}^{2+}$ solutions through a mini-column packed with $30.0 \mathrm{mg}$ of 3-MPTMS-grafted CB. The absorbance was taken as analytical responses. The overall design was performed in duplicate and the data was converted into a Pareto chart (Figure 6) at the 95\% confidence level, in order to study the influence of each factor on the preconcentration system. Horizontal bars from the Pareto chart higher than the vertical line establish the significance of factors. Therefore, as observed, the EC in the experimental domain (1.0-1.5 $\left.\mathrm{mol} \mathrm{L}^{-1}\right)$ did not exert influence on the analytical signal, thus the lowest value $\left(1.0 \mathrm{~mol} \mathrm{~L}^{-1} \mathrm{HCl}\right)$ was chosen for further experiments. The PFR showed a negative 

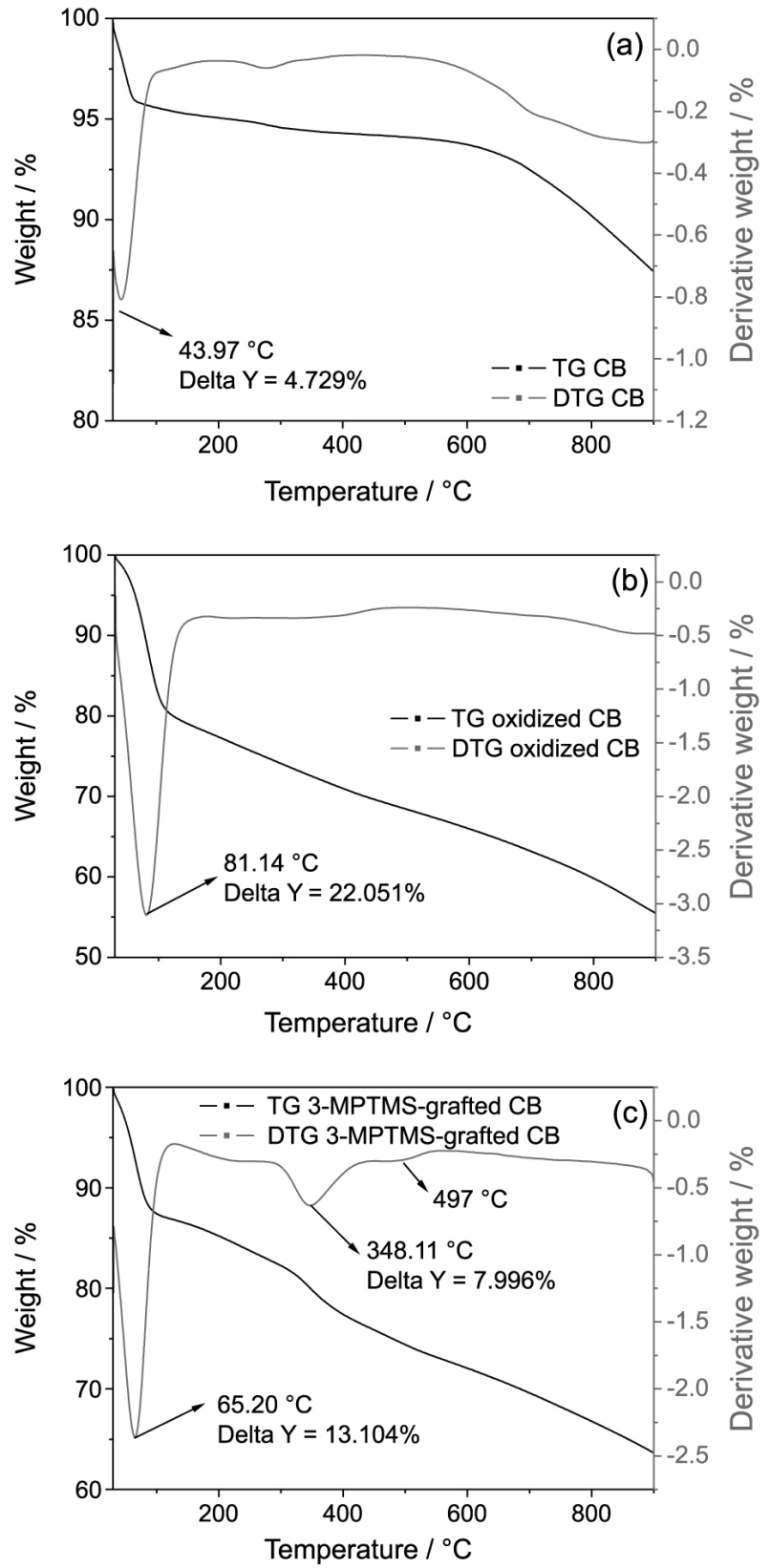

Figure 5. Thermogravimetric curve (TG) and derivative thermogravimetric curve (DTG) from (a) carbon black (CB); (b) oxidized CB; and (c) 3-mercaptopropyltrimethoxysilane (3-MPTMS)-grafted CB.

standardized effect (-3.74), meaning that the use of lower flow rate $\left(4.0 \mathrm{~mL} \mathrm{~min}^{-1}\right)$ increases the retention rate of $\mathrm{Cd}^{2+}$ on the 3-MPTMS-grafted CB. This finding demonstrates that the kinetics of the $\mathrm{Cd}^{2+}$ retention onto the 3-MPTMSgrafted $\mathrm{CB}$ is not too fast. Regarding the $\mathrm{BC}$ on the system, it was noticed that higher concentration $\left(0.1 \mathrm{~mol} \mathrm{~L}^{-1}\right)$ promotes significant increase in the analytical signal of $\mathrm{Cd}^{2+}$.

The positive standardized effect (7.71) of the sample $\mathrm{pH}$ denotes that the increment of $\mathrm{pH}$ within the experimental domain (4.5-7.5) may increase the $\mathrm{Cd}^{2+}$ retention on the 3-MPTMS-grafted CB. One should note that the interaction
BC $\times$ PFR has been statistically significant (negative standardized effect of -8.40), which clearly demonstrates that these factors cannot be optimized independently each other and further experiments would be required for final optimization. However, once the interaction $\mathrm{BC} \times \mathrm{PFR}$ presents a negative standardized effect, the use of lower preconcentration flow rate will considerably decrease the sample throughput of method, thus the BC and PFR were set at $0.1 \mathrm{~mol} \mathrm{~L}^{-1}$ and $4.0 \mathrm{~mL} \mathrm{~min}{ }^{-1}$, respectively, as optimum conditions. Bearing in mind that $\mathrm{BC}$ was set as $0.1 \mathrm{~mol} \mathrm{~L}^{-1}$, the final optimization of $\mathrm{pH}$ was optimized by means of a univariate strategy. The influence of $\mathrm{pH}$ was then investigated in a wide range (4.0-8.0) using buffer solutions acetate and Tris- $\mathrm{HCl}$ at a concentration of $0.1 \mathrm{~mol} \mathrm{~L}^{-1}$ depending upon their buffering capacity in the wide $\mathrm{pH}$ range. Assays were performed in triplicate and were carried out by loading $20.0 \mathrm{~mL}$ of $10.0 \mu \mathrm{g} \mathrm{L}-1 \mathrm{Cd}^{2+}$ solution, and elution was carried out with $1.0 \mathrm{~mol} \mathrm{~L}^{-1} \mathrm{HCl}$ at a flow rate of $4.0 \mathrm{~mL} \mathrm{~min}^{-1}$. The achieved results corroborate the multivariate study, in which the higher $\mathrm{Cd}^{2+}$ retention on the 3-MPTMS-grafted CB takes place at higher $\mathrm{pH}$ values. The decrease of analytical signal at $\mathrm{pH} 8.0$ can be explained most likely due to formation of hydroxide species of cadmium, such as $\mathrm{Cd}(\mathrm{OH})^{+}$which makes the retention of cadmium less effective. According to the aforementioned, the optimum conditions for the preconcentration system were: $\mathrm{pH} 7.0,0.1 \mathrm{~mol} \mathrm{~L}^{-1}$ Tris- $\mathrm{HCl}$ as buffer solution, $1.0 \mathrm{~mol} \mathrm{~L}^{-1} \mathrm{HCl}$ as eluent concentration

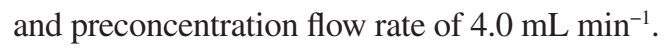

\section{Interference studies}

Table 3 shows the competitive sorption results for the binary mixture of $\mathrm{Cd}^{2+}$ and containing possible interfering ions. In general, the satisfactory selectivity can be attested according to low variation percentage of the analytical signal of $\mathrm{Cd}^{2+}$ (-16 up to $13 \%$ ) even in the presence of high concentration of possible interfering ions. From these results it is possible to infer that the proposed method can be free from matrices effect in different kind of samples, as it will be further demonstrated in the application of method in water sample, saline water $(\mathrm{NaCl} 0.9 \%, \mathrm{~m} / \mathrm{v})$ and cigarette and biological sample (certified reference material). The influence of organic mater on the $\mathrm{Cd}^{2+}$ preconcentration was also evaluted. Cadmium was preconcentrated in the presence of $1.0 \mathrm{mg} \mathrm{L}^{-1}$ humic acid, which has been considered a normal concentration of humic substances in natural water samples. ${ }^{45}$ The variation percentage was found to be $-15 \%$, thus indicating low influence of humic acid on the $\mathrm{Cd}^{2+}$ preconcentration. This result corroborates the feasibility of $\mathrm{Cd}^{2+}$ determination in lake water samples free of interference using an external analytical curve. 
Table 2. Factors and levels obtained using $2^{4}$ full factorial design

\begin{tabular}{|c|c|c|c|c|c|c|}
\hline \multirow[t]{2}{*}{ Factor } & & \multicolumn{5}{|c|}{ Level } \\
\hline & & \multicolumn{3}{|c|}{$(-)$} & \multicolumn{2}{|c|}{$(+)$} \\
\hline $\mathrm{pH}$ & & \multicolumn{3}{|c|}{$4.5^{\mathrm{a}}$} & \multicolumn{2}{|c|}{$7.5^{\mathrm{b}}$} \\
\hline $\mathrm{PFR} /\left(\mathrm{mL} \mathrm{min}^{-1}\right)$ & & \multicolumn{3}{|c|}{4.0} & \multicolumn{2}{|c|}{8.0} \\
\hline $\mathrm{BC} /\left(\mathrm{mol} \mathrm{L}^{-1}\right)$ & & \multicolumn{3}{|c|}{0.01} & \multicolumn{2}{|c|}{0.10} \\
\hline $\mathrm{EC} /\left(\mathrm{mol} \mathrm{L}^{-1}\right)$ & & \multicolumn{3}{|c|}{1.0} & \multicolumn{2}{|c|}{1.5} \\
\hline Assay & $\mathrm{pH}$ & PFR & $\mathrm{BC}$ & $\mathrm{EC}$ & Absorbance / (peak height) & Absorbance / (peak height) \\
\hline 1 & $+(7.5)$ & $+(8)$ & $+(0.1)$ & $+(1.5)$ & 0.404 & 0.391 \\
\hline 2 & $-(4.5)$ & $+(8)$ & $+(0.1)$ & $+(1.5)$ & 0.322 & 0.304 \\
\hline 3 & $+(7.5)$ & $-(4)$ & $+(0.1)$ & $+(1.5)$ & 0.438 & 0.419 \\
\hline 4 & $-(4.5)$ & $-(4)$ & $+(0.1)$ & $+(1.5)$ & 0.410 & 0.369 \\
\hline 5 & $+(7.5)$ & $+(8)$ & $-(0.01)$ & $+(1.5)$ & 0.310 & 0.325 \\
\hline 6 & $-(4.5)$ & $+(8)$ & $-(0.01)$ & $+(1.5)$ & 0.247 & 0.257 \\
\hline 7 & $+(7.5)$ & $-(4)$ & $-(0.01)$ & $+(1.5)$ & 0.259 & 0.262 \\
\hline 8 & $-(4.5)$ & $-(4)$ & $-(0.01)$ & $+(1.5)$ & 0.260 & 0.251 \\
\hline 9 & $+(7.5)$ & $+(8)$ & $+(0.1)$ & $-(1.0)$ & 0.342 & 0.311 \\
\hline 10 & $-(4.5)$ & $+(8)$ & $+(0.1)$ & $-(1.0)$ & 0.305 & 0.325 \\
\hline 11 & $+(7.5)$ & $-(4)$ & $+(0.1)$ & $-(1.0)$ & 0.422 & 0.404 \\
\hline 12 & $-(4.5)$ & $-(4)$ & $+(0.1)$ & $-(1.0)$ & 0.347 & 0.388 \\
\hline 13 & $+(7.5)$ & $+(8)$ & $-(0.01)$ & $-(1.0)$ & 0.349 & 0.347 \\
\hline 14 & $-(4.5)$ & $+(8)$ & $-(0.01)$ & $-(1.0)$ & 0.250 & 0.247 \\
\hline 15 & $+(7.5)$ & $-(4)$ & $-(0.01)$ & $-(1.0)$ & 0.262 & 0.256 \\
\hline 16 & $-(4.5)$ & $-(4)$ & $-(0.01)$ & $-(1.0)$ & 0.304 & 0.289 \\
\hline
\end{tabular}

${ }^{\mathrm{a}}$ Acetate/acetic acid buffer; ${ }^{\mathrm{b}}$ phosphate buffer. BC: Buffer concentration; EC: eluent concentration; PFR: preconcentration flow rate. The values in parentheses are the real values of factors.

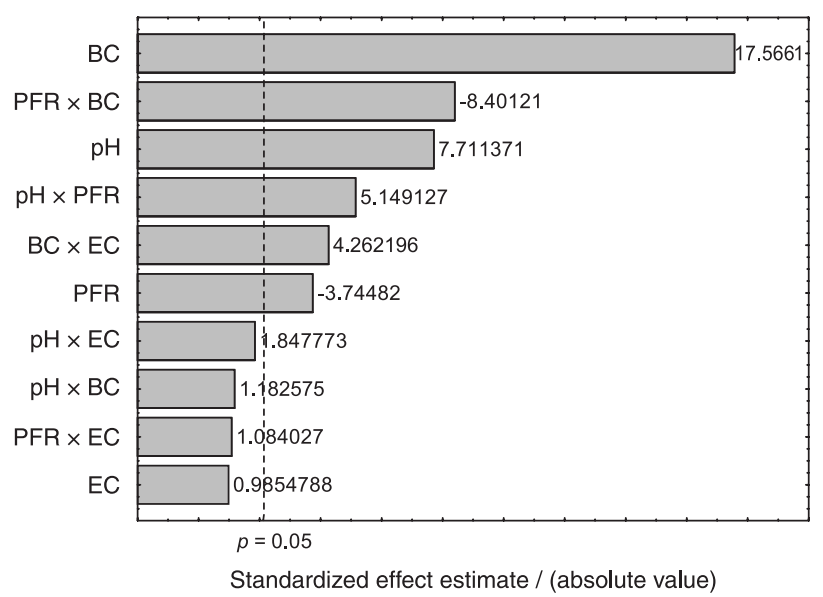

Figure 6. Pareto chart obtained from $2^{4}$ full factorial design. BC: Buffer concentration; PFR: preconcentration flow rate; and EC: eluent concentration.

\section{Characteristics of the proposed method}

Under optimized conditions, the proposed method presented a analytical curve with preconcentration step in the range of 2.0-40.0 $\mu \mathrm{g} \mathrm{L}^{-1}$ yielding the linear equation:
Table 3. Variation percentage of the analytical signal of $\mathrm{Cd}^{2+}$ in the presence of other metal ions

\begin{tabular}{lccccc}
\hline & \multicolumn{5}{c}{ Variation of analytical signal of $\mathrm{Cd}^{2+} / \%$} \\
\cline { 2 - 6 } Possible & \multicolumn{5}{c}{$\mathrm{Cd}^{2+}$ : interferent } \\
\cline { 2 - 6 } & $1: 1$ & $1: 5$ & $1: 10$ & $1: 50$ & $1: 200$ \\
\hline $\mathrm{Co}^{2+}$ & 12 & 9 & -16 & -12 & $\mathrm{NI}$ \\
$\mathrm{Zn}^{2+}$ & 3 & 10 & -7 & -7 & $\mathrm{NI}$ \\
$\mathrm{Ni}^{2+}$ & 2 & 8 & 8 & -3 & $\mathrm{NI}$ \\
$\mathrm{Cu}^{2+}$ & 12 & 10 & -4 & -2 & $\mathrm{NI}$ \\
$\mathrm{Sb}^{2+}$ & -7 & 3 & -4 & -2 & $\mathrm{NI}$ \\
$\mathrm{Pb}^{2+}$ & 13 & -9 & 7 & 0 & $\mathrm{NI}$ \\
$\mathrm{Fe}^{3+}$ & -8 & -1 & 2 & 2 & $\mathrm{NI}$ \\
$\mathrm{As}^{3+}$ & -10 & -1 & -1 & 5 & $\mathrm{NI}$ \\
$\mathrm{Ca}^{2+}$ & $\mathrm{NI}$ & $\mathrm{NI}$ & $\mathrm{NI}$ & -6 & -2 \\
$\mathrm{Ba}^{2+}$ & $\mathrm{NI}$ & $\mathrm{NI}$ & $\mathrm{NI}$ & 1 & -1 \\
$\mathrm{Mg}^{2+}$ & $\mathrm{NI}$ & $\mathrm{NI}$ & $\mathrm{NI}$ & 3 & 5 \\
\hline
\end{tabular}

NI: Level not investigated. 
Abs $=-3.00 \times 10^{-3}+1.37 \times 10^{-2}\left[\mathrm{Cd}^{\mathrm{II}}, \mathrm{mg} \mathrm{L}^{-1}\right]$

with good correlation coefficient $(r=0.9997)$. The analytical curve without preconcentration step was built in the range of 100.0 to $600.0 \mu \mathrm{g} \mathrm{L}{ }^{-1}$ giving rise to a linear equation:

Abs $=8.00 \times 10^{-4}+3.70 \times 10^{-4}\left[\mathrm{Cd}^{\mathrm{II}}, \mathrm{mg} \mathrm{L}^{-1}\right]$

and $r=0.9995$. Significant improvement on sensitivity was observed after implementing the preconcentration step, yielding in a higher preconcentration factor (PF) of 37. This parameter was determined as the ratio between the slopes calculated for the $\mathrm{Cd}^{2+}$ preconcentration using 3-MPTMS-grafted $\mathrm{CB}$ and the $\mathrm{Cd}^{2+}$ direct aspiration into the FAAS (without preconcentration). ${ }^{46}$

The LOD and limit of quantification (LOQ), calculated according to the International Union of Pure and Applied Chemistry (IUPAC) reccomendation as three and ten times the standard deviation for the blank solution $(n=10)$ were found to be 0.20 and $0.66 \mu \mathrm{g} \mathrm{L}^{-1}$, respectively. ${ }^{47}$ The values of concentration efficiency (CE), consumptive index (CI) and sample throughput were determined as described in the literature and were found to be $7.35 \mathrm{~min}^{-1}, 0.54 \mathrm{~mL}$ and $12 \mathrm{~h}^{-1}$, respectively. ${ }^{48}$ The precison of method, evaluated in terms of repeatability for 10 measurements, was found to be 2.8 and $1.4 \%$ (relative standard deviation) for respective concentrations of 5.0 and $40.0 \mu \mathrm{g} \mathrm{L}^{-1}$ of $\mathrm{Cd}^{2+}$. In order to evaluate whether the silanization of $\mathrm{CB}$ with the 3-MPTMS promotes, in fact, improvements on the $\mathrm{Cd}^{2+}$ FAAS determination, one analytical curve for oxidized CB was also obtained the following linear equation:

Abs $=1.21 \times 10^{-23}+9.30 \times 10^{-3}\left[\mathrm{Cd}^{\mathrm{II}}, \mathrm{mg} \mathrm{L}^{-1}\right]$
It was observed an increase of $46 \%$ on the sensitivity for the $\mathrm{Cd}^{2+}$ determination, when using the 3-MPTMS-grafted CB, which clearly demonstrated that functionalized material has great capacity for sorption of $\mathrm{Cd}^{2+}$ even having lower surface area than oxidized CB.

The present method, when compared to previous preconcentration procedures based on solid phase extraction using others carbonaceous materials, such as carbon nanotube and graphene for $\mathrm{Cd}^{2+}$ determination by FAAS (Table 4), provides similar LOD, but greater analytical performance in terms of sample consumption, preconcentration factor, sample throughput, owing to the flow injection system implemented and consumptive index. In addition to this finding, it must be point out that the $\mathrm{CB}$ is extremely cheap once we have received $1 \mathrm{~kg}$ of material free of charge by the supplier Cabot Corporation ${ }^{\circledR}$ (São Paulo, SP, Brazil). The material has proven to be extremely stable under several preconcentration/elution cycles, once more than 300 cycles were carried out in overall study without loss of sorption capacity of material. Therefore, up to now it is impossible to affirm accurately the life-time of material. Although very interesting as adsorbent, it is worth noting the crucial careful for handling CB since in general, this material in similar way to another nano-carbonaceous materials, may cause adverse biological outcomes for humans, such as inflammation, genotoxicity and cell death induction. ${ }^{48}$ Anyway, once packed into a mini-column the handling practically is no more need due to high reusability of material.

\section{Breakthrough curve}

Breakthrough curve depicted in Figure 7 shows that breakthrough volume was found to be $4.0 \mathrm{~mL}$, which

Table 4. Comparative data of some preconcentration systems for $\mathrm{Cd}^{2+}$ determination by flame atomic absorption spectrometry (FAAS) using nanocarbonaceous materials as adsorbents

\begin{tabular}{|c|c|c|c|c|c|c|c|c|c|}
\hline Material & Modifier & $\begin{array}{l}\text { Preconcentration } \\
\text { modality }\end{array}$ & Eluent & $\begin{array}{l}\mathrm{LOD} / \\
\left(\mu \mathrm{g} \mathrm{L}^{-1}\right)\end{array}$ & $\begin{array}{l}\text { Linear range / } \\
\left(\mu \mathrm{g} \mathrm{L}^{-1}\right)\end{array}$ & $\mathrm{PV} / \mathrm{mL}$ & $\mathrm{PF}$ & $\mathrm{CI} / \mathrm{mL}$ & Reference \\
\hline MWCNT & PAN & off-line & $\begin{array}{l}\mathrm{HNO}_{3} \text { in } \\
\text { acetone }\end{array}$ & 0.43 & $5.0-120.0$ & 200 & 40.0 & 5.00 & 49 \\
\hline MWCNT & $\begin{array}{c}\text { oxidized with } \\
\mathrm{KMnO}_{4}\end{array}$ & off-line & $\mathrm{HNO}_{3}$ & 0.15 & $0.5-50.0$ & 250 & - & - & 50 \\
\hline MWCNT & 3-MPTMS & on-line & $\mathrm{HCl}$ & 0.15 & $1.0-60.0$ & 20 & 31.5 & 0.63 & 7 \\
\hline MWCNT & P2AT & off-line & $\mathrm{HNO}_{3}$ & 0.30 & $1.0-100.0$ & 500 & - & - & 51 \\
\hline $\begin{array}{l}\text { Graphene } \\
\text { nanosheet }\end{array}$ & $\begin{array}{l}\text { reduction of } \\
\text { oxidized graphite } \\
\text { with hydrazine }\end{array}$ & off-line & $\mathrm{HCl}$ & 0.20 & $0.3-28.8$ & 50 & 100.0 & 2.00 & 52 \\
\hline Carbon black & 3-MPTMS & on-line & $\mathrm{HCl}$ & 0.20 & $2.0-40.0$ & 20 & 37.0 & 0.54 & Present work \\
\hline
\end{tabular}

CI: Consumptive index; LOD: limit of detection; MWCNT: multi-walled carbon nanotube; PAN: 1-(2-pyridylazo)-2-naphthol; PF: preconcentration factor; PV: preconcentration volume; P2AT: poly(2-amino thiophenol); 3-MPTMS: 3-mercaptopropyltrimethoxysilane. 
corresponds to a retention of $0.040 \mathrm{mg}$ of $\mathrm{Cd}^{2+}$ per gram of 3-MPTMS-grafted CB. This result was very useful for evaluating the sorption rate of $\mathrm{Cd}^{2+}$ onto 3-MPTMS-grafted $\mathrm{CB}$ during construction of analytical curve. Taken the last point of analytical curve, i.e, $40.0 \mu \mathrm{g} \mathrm{L}^{-1}$ of $\mathrm{Cd}^{2+}$, the uptake of metal is $0.026 \mathrm{mg} \mathrm{g}^{-1}$, which is lower than the one achieved from breakthrough volume, thus indicating that $\mathrm{Cd}^{2+}$ is completely adsorbed by material during construction of analytical curve. Moreover, from the result achieved by the breakthrough volume, the sample preconcentration volume can be increased from 20.0 to $30.0 \mathrm{~mL}$, without losses of uptake capacity of material and, as consequence, the LOD and LOQ of method could be decreased.

The column saturation was achieved by loading $492.0 \mathrm{~mL}$ of $0.3 \mathrm{mg} \mathrm{L}^{-1} \mathrm{Cd}^{2+}$ solution, yielding in a MSC of $1.71 \mathrm{mg} \mathrm{g}^{-1}$. This value was over 3.6 times greater than that reported in literature for MWCNT functionalized with 3- MPTMS. ${ }^{7}$

\section{Application of the proposed method}

In order to check the accuracy and validity for real samples, the proposed method was applied to the $\mathrm{Cd}^{2+}$ in different kind of samples and certified reference material. As shown in Table 5, $\mathrm{Cd}^{2+}$ at trace levels was found in mineral, tap, saline and lake water samples as well as in cigarrete sample. Recovery experiments of different amount of $\mathrm{Cd}^{2+}$ by using analytical external curve were performed given rise to satisfactory recoveries (92-99\%), thus attesting the accuracy and applicability of the method free of interferences. Although $\mathrm{Cd}^{2+}$ has been quantified in drinking water, the amount achieved was lower than that maximum level recognized by US EPA ${ }^{3}$ and ANVISA. ${ }^{4}$

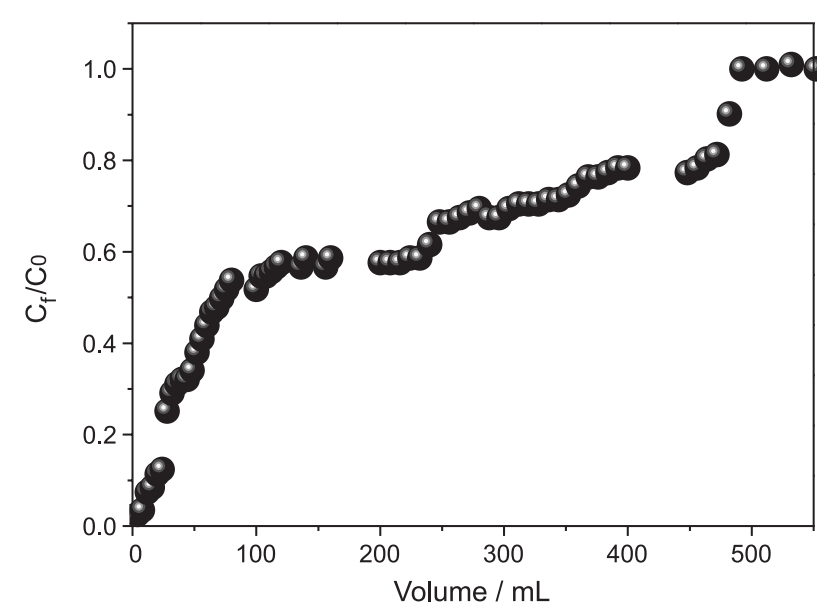

Figure 7. Breakthrough curve of 3-mercaptopropyltrimethoxysilane (3-MPTMS)-grafted carbon black (CB) using $0.3 \mathrm{mg} \mathrm{L}^{-1}$ cadmium at a flow rate $4.0 \mathrm{~mL} \mathrm{~min}^{-1} . \mathrm{C}_{\mathrm{f}}$ : Cadmium concentration in the column effluent; $\mathrm{C}_{0}$ : initial cadmium concentration, $0.3 \mathrm{mg} \mathrm{L}^{-1}$.

Regarding cigarette sample, it is known that in the absence of occupational exposure, the main sources of $\mathrm{Cd}^{2+}$ uptake are food and tobacco smoke. Therefore, the element has been included in the list of harmful and potentially harmful constituents in tobacco products and tobacco smoke according to US Food and Drug Administration (FDA). ${ }^{53}$ The amount of $\mathrm{Cd}^{2+}$ obtained in the present study was slightly higher and lower than those amounts determined by Andrade et al. ${ }^{54}$ and Lemos et al. ${ }^{55}$ respectively, in cigarettes commercialized in Brazil. The amount of $\mathrm{Cd}^{2+}$ also determined in certified reference (TORT-2, lobster hepatopancreas) by this method $\left(26.47 \pm 0.25 \mu \mathrm{g} \mathrm{g}^{-1}\right.$, $\mathrm{n}=3$ ) was statistically equal to the certified value $\left(26.7 \pm 0.6 \mu \mathrm{g} \mathrm{g}^{-1}\right)$ with $95 \%$ confidence interval (Student's $t$-test), thus confirming the accuracy of the proposed method even for biological sample submitted to acid digestion.

Table 5. Quantification and recovery of $\mathrm{Cd}^{2+}$ in different kind of samples

\begin{tabular}{|c|c|c|c|}
\hline Sample & Amount added of $\mathrm{Cd}^{2+} /\left(\mu \mathrm{g} \mathrm{L}^{-1}\right)$ & Amount found of $\mathrm{Cd}^{2+} /\left(\mu \mathrm{g} \mathrm{L}^{-1}\right)$ & Recovery / \% \\
\hline \multirow{3}{*}{ Mineral water } & 0 & $0.85 \pm 0.08$ & - \\
\hline & 10 & $10.62 \pm 0.15$ & 98 \\
\hline & 30 & $30.26 \pm 0.39$ & 98 \\
\hline \multirow{3}{*}{ Tap water } & 0 & $0.97 \pm 0.04$ & - \\
\hline & 10 & $10.39 \pm 0.28$ & 95 \\
\hline & 30 & $30.03 \pm 0.19$ & 97 \\
\hline \multirow{3}{*}{ Saline } & 0 & $0.87 \pm 0.04$ & - \\
\hline & 10 & $10.05 \pm 0.09$ & 92 \\
\hline & 30 & $30.21 \pm 0.24$ & 98 \\
\hline \multirow{3}{*}{ Lake Igapó III ${ }^{\mathrm{a}}$} & 0 & $0.79 \pm 0.04$ & - \\
\hline & 10 & $9.92 \pm 0.15$ & 92 \\
\hline & 30 & $30.10 \pm 0.35$ & 98 \\
\hline \multirow{2}{*}{ Cigarette $^{\mathrm{b}}$} & 0 & $1.17 \pm 0.07$ & - \\
\hline & $15^{\mathrm{b}}$ & $16.10 \pm 0.20$ & 99 \\
\hline
\end{tabular}

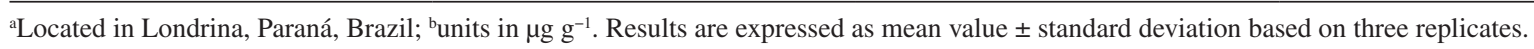




\section{Conclusions}

In the present study, CB chemically modified with 3-MPTMS as organosilane agent was used for the first time as adsorbent for $\mathrm{Cd}^{2+}$ aiming at development of a preconcentration method on-line coupled to FAAS. The results obtained from the characterization of the materials by means of FTIR, Raman, TG and textural analysis were very useful to confirm the oxidation and functionalization of CB with 3-MPTMS. As for the presented method, the use of 3-MPTMS in the CB functionalization improves the sensitivity of the method and when compared to others that make use of more expensive nano-carbonaceous material, such as carbon nanotubes, the advantages of this study is highlighted by low limit of detection, low sample consumption, high preconcentration factor and low cost. Therefore, for final remarks, the 3-MPTMS-grafted CB can be considered as an alternative and efficient nanocarbonaceous adsorbent to be used for preconcentration studies aiming at determination of $\mathrm{Cd}^{2+}$ at low levels.

\section{Acknowledgments}

The authors would like to thank the Conselho Nacional de Desenvolvimento Científico e Tecnológico (CNPq, Project No. 481669/2013-2, 305552/2013-9, 472670/2012-3), Coordenação de Aperfeiçoamento de Pessoal de Nível Superior (CAPES, 25/2014), Fundação Araucária do Paraná (163/2014), Laboratório de Espectroscopia da Central de Multiusuário da Pró-Reitoria de Pesquisa e Pós-Graduação (PROPPG), Companhia de Saneamento do Paraná (SANEPAR) and Instituto Nacional de Ciência e Tecnologia de Bioanalítica (INCT, Project No. 573672/2008-3) for their financial support and fellowships.

\section{References}

1. Mahmoud, M. E.; Osman, M. M.; Ahmed, S. B.; Abdel-Fattah, T. M.; Chem. Eng. J. (Amsterdam, Neth.) 2011, 175, 84.

2. Fan, H.-T.; Li, J.; Li, Z.-C.; Sun, T.; Appl. Surf. Sci. 2012, 258, 3815.

3. United States Environmental Protection Agency (US EPA); National Primary Drinking Water Standards, Maximum Contaminant Level; U.S. Agency Office of Water: Washington D.C., August 2003.

4. Agência Nacional de Vigilância Sanitária (ANVISA); Procedimentos de Controle e de Vigilância da Qualidade da Água para Consumo Humano e seu Padrão de Portabilidade, Resolution - RE No. 2.914, 2011.

5. Huff, J.; Lunn, R. M.; Waalkes, M. P.; Tomatis, L.; Infante, P. F.; Int. J. Occup. Environ. Health 2007, 13, 202.
6. Yue, L.; Biomed. Environ. Sci. 1992, 5, 53.

7. Corazza, M. Z.; Somera, B. F.; Segatelli, M. G.; Tarley, C. R. T.; J. Hazard. Mater. 2012, 243, 326.

8. Tüzen, M.; Food Chem. 2003, 80, 119.

9. Yang, G.; Fen, W.; Lei, C.; Xiao, W.; J. Hazard. Mater. 2009, $162,44$.

10. Zhang, N.; Hu, B.; Anal. Chim. Acta 2012, 723, 54.

11. Silva, E. L.; Roldan, P. S.; Ginéa, M. F.; J. Hazard. Mater. 2009, $171,1133$.

12. Feist, B.; Mikula, B.; Food Chem. 2014, 147, 302.

13. Arpa, C.; Bektas, S.; Anal. Sci. 2006, 22, 1025.

14. Rekha, D.; Suvardhan, K.; Kumar, J. D.; Subramanyam, P.; Prasad, P. R.; Lingappa, Y.; Chiranjeevi, P.; J. Hazard. Mater. 2007, 146, 131.

15. Vellaichamy, S.; Palanivelu, K.; J. Hazard. Mater. 2011, 185, 1131.

16. Pyrzynska, K.; Anal. Sci. 2007, 23, 631.

17. Tarley, C. R. T.; Barbosa, A. F.; Segatelli, M. G.; Figueiredo, E. C.; Luccas, P. O.; J. Anal. At. Spectrom. 2006, 21, 1305.

18. Tuzen, M.; Saygi, K. O.; Soylak, M.; J. Hazard. Mater. 2008, 152,632 .

19. Gallego, M.; de Pena, Y. P.; Valcárcel, M.; Anal. Chem. 1994, 66, 4074.

20. Ensafi, A. A.; Ghaderi, R. A.; J. Hazard. Mater. 2007, 148, 319.

21. Yu, J.-G.; Yu, L.-Y.; Yang, H.; Liu, Q.; Chen, X.-H.; Sci. Total Environ. 2015, 502, 5274.

22. Valenzuela-Calahorro, C.; Navarrete-Guijosa, A.; Stitou, M.; Cuerda-Correa, E. M.; Appl. Surf. Sci. 2007, 253, 5274.

23. Jansen, R. J. J.; Vanbekkum, H.; Carbon 1994, 32, 1507.

24. Noked, M.; Soffer, A.; Aurbach, D. J.; Solid-State Electron. 2011, 15, 1563.

25. Meiriane, C. F.; Soares, M. M.; Viana, Z. L.; Schaefer, V. S.; Gangoli, Y. C.; Caliman, V.; Wong, M. S.; Silva, G. G.; Carbon 2014, 72, 287.

26. Atif, M.; Bongiovanni, R.; Giorcelli, M.; Celasco, E.; Tagliaferro, A.; Appl. Surf. Sci. 2013, 286, 142.

27. Baikousi, M.; Dimos, K.; Bourlinos, A. B.; Zbořil, R.; Papadas, I.; Deligiannakis, Y.; Karakassides, M. A.; Appl. Surf. Sci. 2012, 258, 3703.

28. Cheng, M. P.; Jang, K. K.; Zhong, T. B.; Carbon 2006, 44, 3233.

29. Ma, P. C.; Kim, J. K.; Tang, B. Z.; Carbon 2006, 44, 3232.

30. Peng, H.; Zhang, N.; He, M.; Chen, B.; Hu, B.; Talanta 2015 , $131,266$.

31. Torkian, L.; Amini, M. M.; Gorji, T.; Sadeghi, O.; Arabian J. Chem., in press, DOI: 10.1016/j.arabjc.2014.10.041.

32. Somera, B. F.; Corazza, M. Z.; Yabe, M. J. S.; Segatelli, M. G.; Galunin, E.; Tarley, C. R. T.; Water, Air, Soil Pollut. 2012, 223, 6069.

33. O’Reilly, J. M.; Mosher, R. A.; Carbon 1983, 21, 47.

34. Qiuying, L.; Carbon 2007, 45, 2411. 
35. Kathi, J.; Rhee, K.; Lee, J. H.; Composites, Part A 2009, 40, 800.

36. Velasco-Santos, C.; Martínez-Hernandez, A. L.; Lozada-Cassou, M.; Alvarez- Castillo, A.; Castaño, V. M.; Nanotechnology 2002, $13,495$.

37. Filho, V. R. A.; Polito, W. L.; Gomes Neto, J. A.; J. Braz. Chem. Soc. 2007, 18, 47.

38. Boyaci, E.; Çagir, A.; Shahwan, T.; Eroglu, A. E.; Talanta 2011, 85, 1517.

39. Avilés, F.; Sierra-Chi, C. A.; Nistal, A.; May-Pat, A.; Rubio, F.; Rubio, J.; Carbon 2013, 57, 520.

40. Gaspar, H.; Pereira, C.; Rebelo, S. L. H.; Pereira, M. F. R.; Figueiredo, J. L.; Freire, C.; Carbon 2011, 49, 3441.

41. Mohan, A. N.; Manoj, B.; Int. J. Electrochem. Sci. 2012, 7, 9537.

42. Vukovic, G.; Marinkovic, A.; Obradovi, M.; Radmilovic, V.; Colic, M.; Aleksic, R.; Uskokovic, P. S.; Appl. Surf. Sci. 2009, 255, 8067.

43. Kameya, Y.; Hanamura, K.; Chem. Eng. J. (Amsterdam, Neth.) 2011, 173, 627.

44. Pimenta, M. A.; Dresselhaus, G.; Dresselhaus, M. S.; Cançado, L. G.; Jorio, A.; Saito, R.; Phys. Chem. Chem. Phys. 2007, 9, 1276.

45. Wuilloud, J. C. A.; Wuilloud, R. G.; Sadi, B. B. M.; Caruso, J. A.; Analyst (Cambridge, U. K.) 2003, 128, 453.
46. Tarley, C. R. T.; Corazza, M. Z.; Somera, B. F.; Segatelli, M. G.; J. Colloid Interface Sci. 2015, 450, 254.

47. Long, G. L.; Winefordner, J. D.; Anal. Chem. (Washinghton, DC, U.S.) 1983, 55, 712A.

48. Diniz, K. M.; Segatelli, M. G.; Tarley, C. R. T.; React. Funct. Polym. 2013, 73, 838.

49. Tavallali, H.; Fakhraee, V.; Int. J. ChemTech. Res. 2011, 3, 1628.

50. Jun-Ping, X.; Qing-Xiang, Z.; Hua-Hua, B. J.; J. Environ. Sci. (Beijing, China) 2007, 19, 1266.

51. Nabid, M. R.; Sedghi, R.; Bagheri, A.; Behbahani, M.; Taghizadeh, M.; Oskooie, H. A.; Heravi, M. M; J. Hazard. Mater. 2012, 203, 93.

52. Hallaj, R.; Bahar, S.; Babamiri, B.; Zandi, S.; Can. J. Chem. 2014, 92, 62 .

53. United States Food and Drug Administration (US FDA); 77 FR 20034-20037 - Harmful and Potentially Harmful Constituents in Tobacco Products and Tobacco Smoke; Department of Health and Human Services: Silver Spring, M.D., April, 2012.

54. Andrade, F. P.; Nascentes, C. C.; Costa, L. M.; J. Braz. Chem. Soc. 2009, 20, 1460.

55. Lemos, V. A.; Novaes, C. G.; Lima, A. S.; Vieira, D. R.; J. Hazard. Mater. 2008, 155, 128.

Submitted: December 8, 2015

Published online: February 16, 2016

FAPESP has sponsored the publication of this article. 